\title{
The positive aspects of the natural environment in shaping the regional identity of young people
}

\author{
Maria Adamczewska \\ Department of Geography Teaching, Faculty of Geographical Sciences, University of Lodz, Kopcińskiego Str. 31, 90-142 Łódź, Poland \\ E-mail address: maria.adamczewska@geo.uni.lodz.pl
}

\begin{abstract}
The relations between man and nature constitute an immemorial subject of the geographical research. Man, while striving to understand the surrounding world and its secrets, simultaneously alters and transforms it. The importance of knowing the rules of rational functioning in the natural environment, especially in the modern, globalized world is proven by it being a subject of schooling at all education levels. The purpose of the students gaining knowledge on the natural environment and the rules of its normal functioning in order to provide a balanced development thereof, is also meant to shape appropriate attitudes, consciousness and responsibility for the natural environment, both in the global and local aspects. Therefore, an attempt to determine the significance of the natural environment in shaping the sense of local identity in young people has been made. Studies on the local and regional identity have been conducted with the high schoolers from the Łódź voivodeship using the survey method. The results of the research allowed to determine the level of knowledge on the natural environment in the area of the students' places of residence, including the areas protected by law. A high importance of natural values in shaping the pride of a person's place of residence was also proven. Moreover, it turned out that the advantages of the natural habitat are in a high position in terms of areas considered "magical places". The natural environment values are more likely to shape local identities in students residing in rural areas, in a direct neighbourhood of protected areas, forests or rivers.
\end{abstract}

KEY WORDS: ties, Łódź voivodeship, high school students

\section{Introduction}

Shaping a regional identity, especially in the young, is both extremely hard and determined by multiple factors. A regional identity is created mostly on the basis of connections with a certain area and its important characteristics (SZCZEPAŃSKI, 1999; LISOWSKI, 2003). SZUL (1991), SZYMAŃSKA (1999), Rembowska (2002) emphasize the significance of emotional relationships in the process of shaping the identification, the emotional sense of identification of man with a given area, its landscape, inhabitants, the products of material and spiritual culture and its symbols in connection with the issue of regional identity.

Educational factors, such as school - where young people gain knowledge regarding the reality that surrounds them - have an important role in shaping the regional identity (ADAMCZEWSKA \& SZKURŁAT, 2008). The natural environment of especially valuable areas, those protected by law, is used to further the ecological, geographical and regional education (PULINOWA, 1996; ANGIEL \& ANGIEL, 2001; JANOWSKI, 2003; DoBOSIK ET AL., 2004; HIBSZER, 2004).

Non-educational factors constitute another group of factors that shape regional identity - those, in turn, comprise internal factors which are related to man himself and his system of values, and external factors which depend on the characteristics of a given area (Rodzoś, 2006). In this case, the positive aspects of natural environment are considered external factors. The attractiveness of landscape enables the identification with a given place or area and plays an important role in shaping a regional identity. According to PuLinowA "the landscape that we commune with daily, in which we immerse ourselves [...] is [...] the basis on which we shape our identity. Not only the relationships with people, but also those with the natural and 
cultural environment are crucial for the integral human development, to grow healthily and in wisdom" (2001, p. 12; all quotations in this article are rendered by a translator). Frequently, one of the first objects of such type are the natural ones - e.g. a favourite path, road in the forest, park, a favourite spot by the river, lake, a hill with a view on the neighbourhood, and the like.

In the article, the attempt has been made to determine the significance of the positive aspects of the natural environment, taking into account especially the places most valuable in terms of nature, protected by law, crucial in shaping the regional identity of young people, based on the example of high school students from the Łódź voivodeship. In order to do that, at the beginning, the specification of the natural environment in the researched area will be presented, indicating the areas with the highest natural value - those protected by law. The basis for the research and its conclusions constitutes the results of survey questionnaires conducted among 1327 students, the majority of which were women $(63.8 \%)$. The majority of respondents were $3^{\text {rd }}$ grade students, aged circa $18 \quad(83.8 \%$ of all respondents), attending general-knowledge high schools in the powiat (a second-level unit of local administration in Poland) cities of the Łódź voivodeship and high schools in Koluszki, Przedbórz and Szczerców (Fig. 1). The questionnaire surveys were anonymous and voluntary.

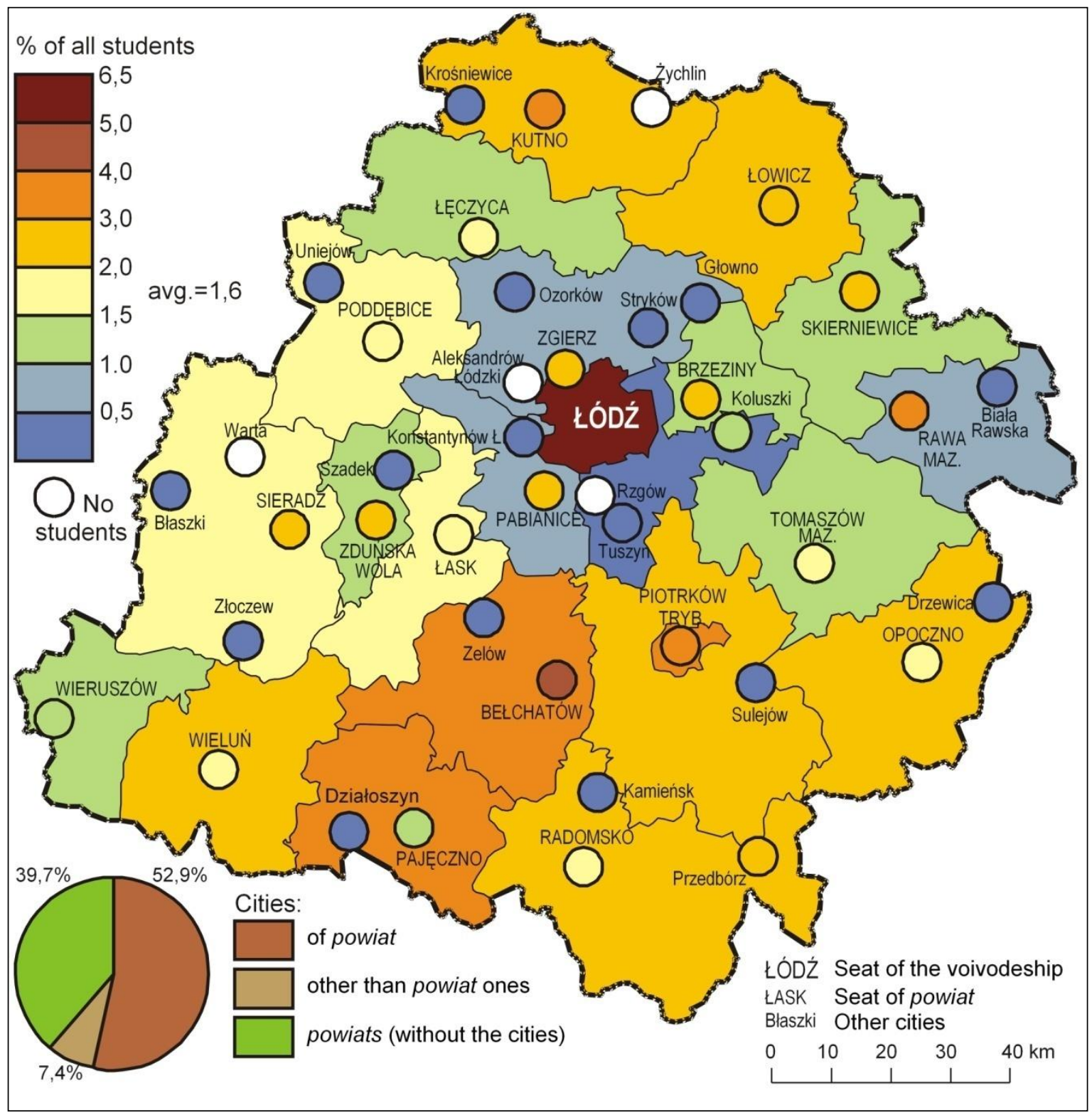

Fig. 1. The spatial diversity of the respondents divided according to the towns and villages in specific powiats [the $\%$ of all respondents] 


\section{The natural environment and the forms of nature protection in the Łódź voivodeship}

The natural environment of the Łódź voivodeship has features that distinguish it from other regions of Poland, but it is also internally diverse. The biggest internal diversity (within the voivodeship) concerns the geological structure, landforms and waters, both surface waters and groundwaters. The remaining elements of natural environment - climate conditions, soil conditions, flora and fauna - are characterized by significantly lower diversity (BURCHARD \& NALEWAJKO, 2000). The internal diversity of individual elements of the natural habitat in the Łódź voivodeship is a result of its unique, central location in the country, on the border of different geographical regions (Fig. 2).

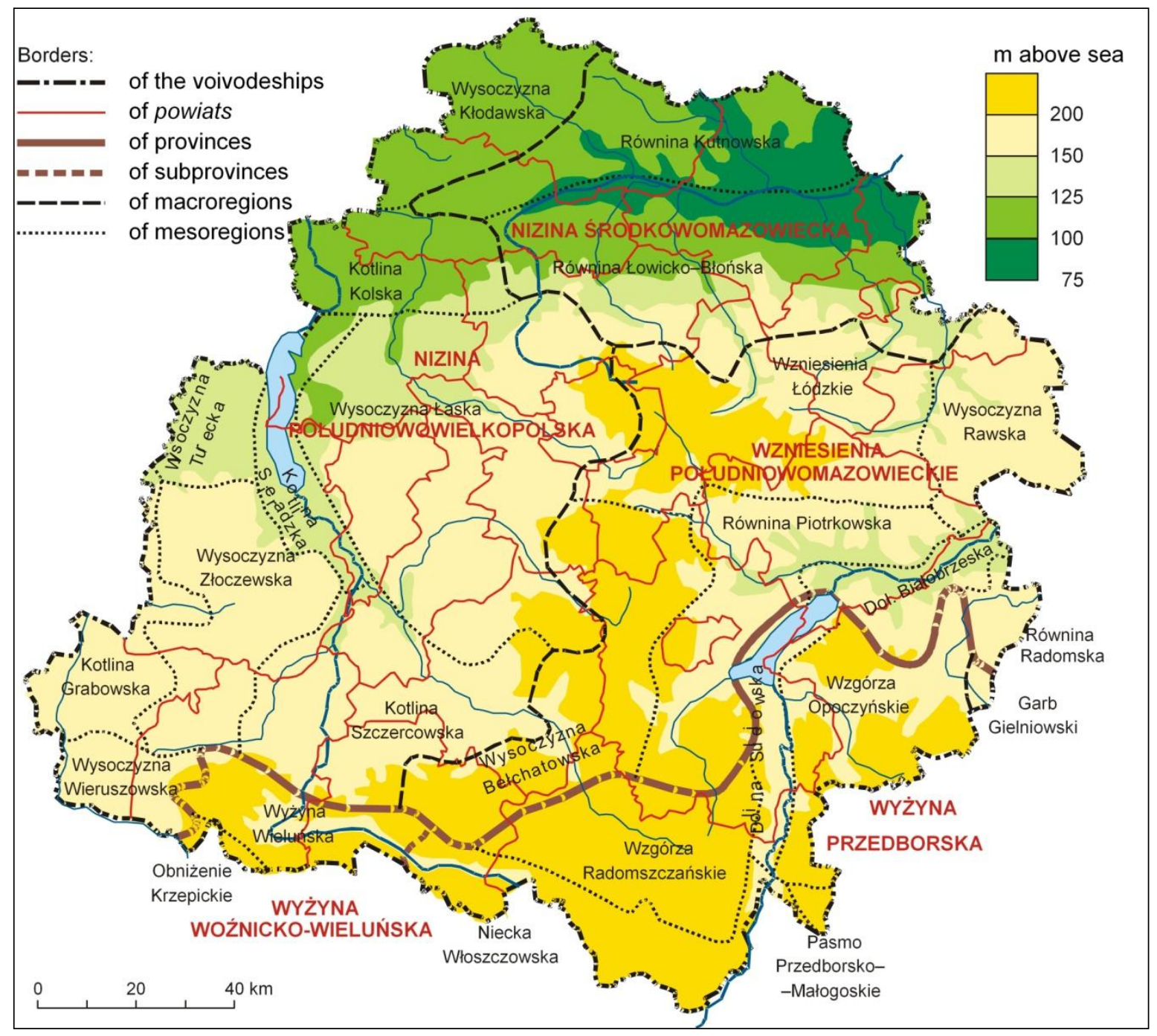

Fig. 2. The surface structure and the physical and geographical division in the Łódź voivodeship (according to Kondracki, 1998)

The area of the Łódź voivodeship constitutes a "bridge" between the uplands of southern Poland and the northern lowlands, which determine the geographical individuality of the area (DYLIK, 1971). One of the symptoms of this individuality is the diversity of landscapes ${ }^{1}$. Lowland landscapes

\footnotetext{
${ }^{1}$ In the subject literature the notion of landscape, despite its numerous definitions (among others: Richling, Solon, 1996; Pietrzak, 2005; Myga-Piątek, 2001; Ostaszewska, 2005), remains, according to Majchrowska (2008) vague and hazy. The most popular criterion of landscape systematization
}

dominate in the northern and central parts of the voivodeship: old-glacial landscape and valleys and plains that are a result of sedimentation, while the upland landscape dominates in the southern and south-eastern areas (KONDRACKI, 1965).

used in texts is their natural attributes, especially the characteristics of abiotic components: terrain, geological structure and soils. The social, economic, technical and cultural, esthetic characteristics are included rarely. In order to present the landscape diversity of the Łódź voivodeship the texts using natural characteristics as the criterion of landscape division were invoked. 
The areas of the Wyżyna Woźnicko-Wieluńska and Wyżyna Przedborska uplands reach heights of 200 to more than $300 \mathrm{~m}$ above sea level, and are built of limestone and sandstone, which are favourable to karst phenomena. The highest natural hill of the Voivodeship is Fajna Ryba - 347 m above sea level, located in the range Pasmo PrzedborskoMałogoskie².

The remaining part of the voivodeship is located in the strip of lowlands, with a central area of quite varied terrain, named Wyżyna Łódzka (the Łódź Upland) 3 (DYLIKowA, 1973). Wyżyna Łódzka „unites the characteristics of both uplands and lowlands [...] The primary physical and geographical feature thereof is a bump with hills higher than 200 and, in certain areas, even $280 \mathrm{~m}$ above sea level, which slips between the lowlands from the side of the Ślacko-Małopolska Upland, and constitutes a major axis of the region" (PAPIŃSKA, 1993 after DYLIKOWA, 1973). The lowest regions are located in the northern part of the voivodeship - they comprise the vast areas of the Pradolina WarszawskoBerlińska urstromtal with the Bzura valley.

The natural environment of the Łódź voivodeship is characterized by its radial, centrifugal hydrographic structure. A drainage divide of the $1^{\text {st }}$ level (separating the river basins of major rivers) which separates the river basins of Wisła and Odra runs through the whole area of the voivodeship, north to south. The central part of the voivodeship is the area of the river sources of lesser rivers that flow west, east or north into either of the three major rivers of the region (Warta, Pilica, Bzura) which run through its outskirts (JOKIEL, 2004)4. The Warta and Pilica

\footnotetext{
2 The highest point in the Łódź voivodeship is Mount Kamieńsk - an artificial hill, $386 \mathrm{~m}$ above sea level, which came into being as an outer spoil tip of the coal mine Kopalnia Węgla Brunatnego Bełchatów, located in the radomszczański powiat in the Kamieńsk district. Its relative height amounts to circa $160-180 \mathrm{~m}$.

3 In Kondracki's physical-geographical typology Wyżyna Łódzka is not listed as a unit. The term Wyżyna Łódzka was first introduced in literature by W. Nałkowski in 1913 According to Dylikowa (1973) Wyżyna Łódzka comprises the areas from the Rawka valley in the east to the southern section of Warta in the west. As part of Wyżyna Łódzka, Dylikowa has enumerated the Garb Łódzki hill, Niecka Łęczycka hollow, Kotlina Szczercowska basin, Wysoczyzna Skierniewicka hill, plains: Tomaszów, Piotrków, Szadek.

${ }^{4} \mathrm{On}$ the outskirts, two biggest artificial water basins in the voivodeship have been located. The first one was the Zbiornik Sulejowski basin in the Pilica valley (1973), which initially served as a storage reservoir to provide water for the Łódź agglomeration. In the Warta valley in 1986, Zbiornik Jeziorsko basin was built - the biggest artificial basin in the voivodeship. The surface waters of the Voivodeship also supplement the other artificial water basins created in the valleys of smaller rivers (Widawka, Luciąża, Rawka).
}

valleys also constitute major landforms of the Łódź voivodeship. Due to the winding and deep valleys (20-50 m), $1 \mathrm{~km}$ to $6 \mathrm{~km}$ wide (BURCHARD \& NALEWAJKO, 2000) they are considered as one of the most beautiful forms of landscape within the voivodeship. However, the valleys of smaller rivers, such as Widawka, Grabia, Rawka are no less beautiful.

The groundwaters of the Łódź region are characterized by the rich resources of artesian and subartesian aquifiers (MAKSYMIUK, 1993, 2001) as well as thermal waters. Despite thermal waters being present under the surface of $80 \%$ of Poland (JAWORSKA, 2009), it is the waters under the Łódź voivodeship that have appropriate parameters (among others, the temperature of circa $110^{\circ} \mathrm{C}$, the low level of mineralization, high efficiency), which enable their wide range of usage (GóRECKI, 2001; SMĘTKIEWICZ, 2014). The thermal waters in Uniejów are used for energy, medicinal and recreational purposes.

The other elements of the natural environment of the Łódź voivodeship show lower diversity. The vegetation of the Łódź voivodeship constitutes a reflection of the abiotic elements of the natural environment of the region and human activity. The remains of the old-growth forests have been taken under the protection of law, mostly as nature reserves (Puszcza Bolimowska, Puszcza Pilicka). Currently, the forested areas comprise only 21.3\% (LEŚNICTWO, 2014) of the voivodeship area5. The greatest forestation in the voivodeship (above 30\%) occurs in the powiats - tomaszowski, radomszczański and opoczyński, and the smallest: kutnowski (4.9\%) and łęczycki (5.6\%) (OCHRONA ŚRODOWISKA I LEŚNICTWO..., 2014). The area of the voivodeship is crossed by the northern borderline of the range of the Norway spruce, sycamore, silver fir and the north-western borderline of the range of the common beech (MAKSYMIUK \& OLACZEK, 2001). Moreover, its characteristic feature is the occurence of several dozen species of plants that are typical of uplands and mountains.

The areas with the highest natural value have been taken under the protection of law. In the area of the voivodeship there are no national parks ${ }^{6}$, but it still contains many areas that are valuable in terms of nature. There are 7 landscape

\footnotetext{
5 The index of the forestation of the tódź Voivodeship is decidedly lower that the mean average of the whole country which amounts to 29.4\% (Leśnictwo 2014).

${ }^{6}$ Only Ośrodek Hodowli Żubrów im. prezydenta RP Ignacego Mościckiego in Smardzewice near Tomaszów Mazowiecki is protected as a national park, as part of the Kampinos National Park. Ośrodek Hodowli Żubrów was originally considered a nature reserve, and since 1976 it has been incorporated into the Kampinos National Park.
} 
parks within the voivodeship. The oldest one is the Załęczański Park Krajobrazowy created in 1978 - it is simultaneously one of the oldest landscape parks in Poland. Other landscape parks were created in the following years: Bolimowski PK (1986), Przedborski PK(1988), PK Międzyrzecza Warty i Widawki (1989), Sulejowski PK (1994), Spalski PK (1995) and PK Wzniesień Łódzkich (1996). Three of them: Załęczański, Bolimowski and Przedborski also partially share the the areas of neighbouring voivodeships.
Moreover, in the Łódź voivodeship a lot of elements are protected by law: more than 3.3 thousand of natural monuments, 17 areas of protected landscape, 87 nature reserves - mostly forest reserves, 41 areas of Obszary Natura 2000, and the like (RoCZNIK STATYSTYCZNY..., 2014; KUROWSKI, 2013; PROGRAM OCHRONY ŚRODOWISKA..., 2012). The highest density of protected areas occurs in the valleys of rivers: Pilica, Warta and Widawka, Rawka and in the Wyżyna Wieluńska and Wyżyna Przedborska uplands and on the borderline of Wzniesienia Łódzkie (Fig. 3).

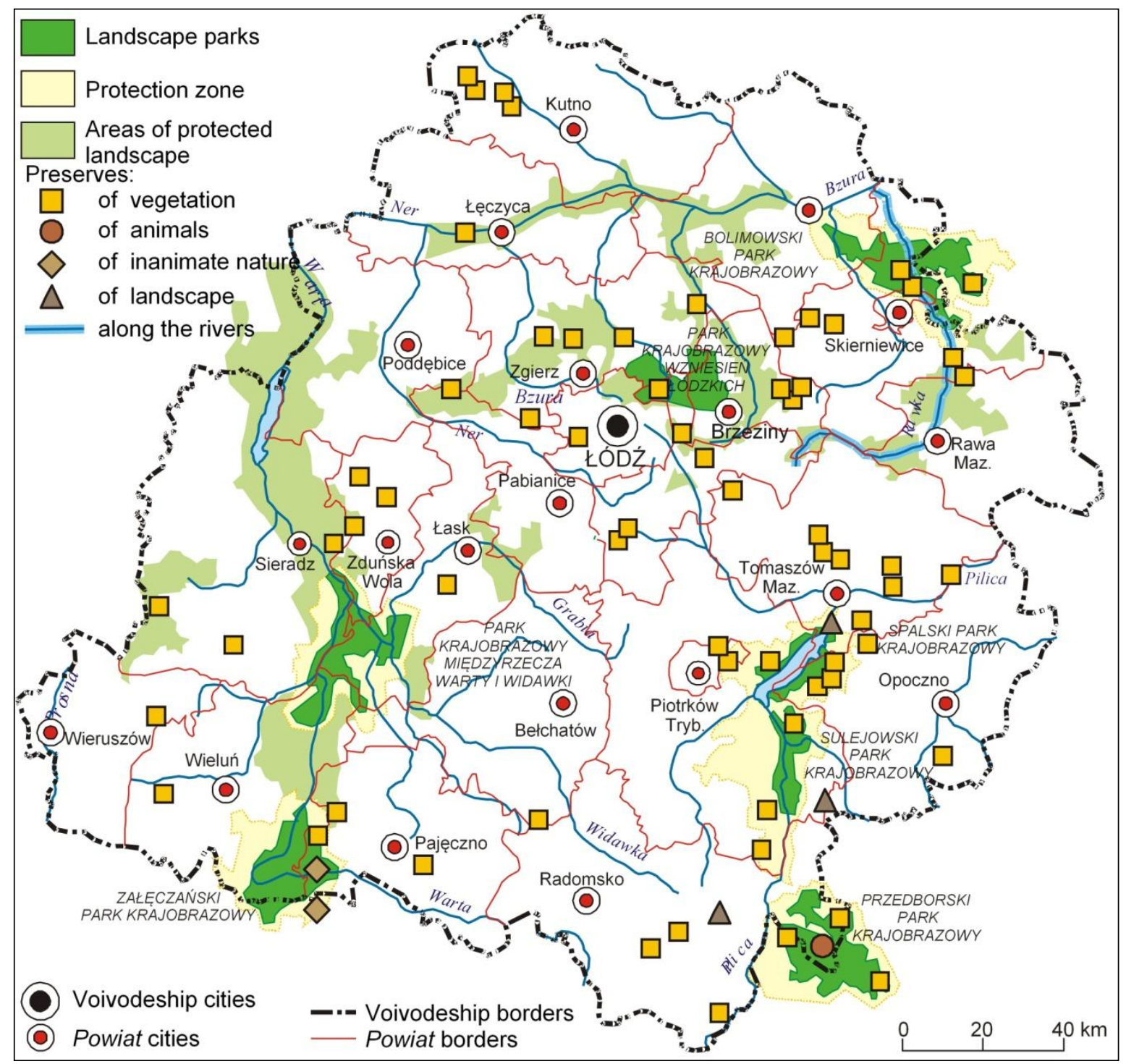

Fig. 3. The main forms of nature protection in the Łódź voivodeship

\section{The results of surveys}

The purpose of the surveys was to determine: 1) the degree of the students' knowledge on the natural environment of the Łódź voivodeship, in particular their own neighbourhood; 2) the students' consciousness on the subject of the existence of protected areas in their neighbourhoods; 3) the importance of nature areas/objects in students' everyday lives (nature areas as "magical places", nature areas/objects in shaping the pride of one's own area of residence, the significance of the nature areas/objects as places of recreation, leisure and spending free time).

The students' level of knowledge on the subject of the natural environment of their area of residence 
is higher than in the whole Łódź voivodeship. Young people were mostly able to identify the selected elements of the natural environment in their places of residence and their neighbourhoods (e.g. landform features, river nets, natural resources) and apply the correct terms for given geographical regions. However, in case of the areas protected by law, the situation appears more complicated to the question of whether there are areas or individual objects considered a wildlife conservation in the region you live in, the definite majority of respondents (71.6\% of all) answered affirmatively (Table 1). Although the enumeration and correct exemplification of the proper names of specific objects constituting wildlife conservations was not equally simple?

Table 1. The existence of wildlife conservation areas, according to students, in their areas of residence

\begin{tabular}{|l|c|}
\hline \multicolumn{1}{|c|}{ Specification } & \% of indications \\
\hline Generally & 71.6 \\
\hline Countryside & 73.1 \\
\hline City & 70.7 \\
\hline Wieruszów & 93.5 \\
\hline Pajęczno & 91.7 \\
\hline Tomaszów Mazowiecki & 91.2 \\
\hline Przedbórz & 89.5 \\
\hline Łódź & 87.1 \\
\hline Koluszki & 86.4 \\
\hline Wieluń & 86.4 \\
\hline Skierniewice & 79.6 \\
\hline Łowicz & 79.0 \\
\hline Łask & 77.8 \\
\hline Piotrków Trybunalski & 77.4 \\
\hline Zduńska Wola & 75.0 \\
\hline Sieradz & 74.6 \\
\hline Zgierz & 74.5 \\
\hline Radomsko & 72.5 \\
\hline Brzeziny & 69.4 \\
\hline Kutno & 66.3 \\
\hline Rawa Mazowiecka & 64.4 \\
\hline Poddębice & 63.0 \\
\hline Szczerców & 62.0 \\
\hline Łęczyca & 51.2 \\
\hline Pabianice & 48.9 \\
\hline Bełchatów & 40.5 \\
\hline Opoczno & 37.3 \\
\hline & \\
\hline & \\
\hline
\end{tabular}

${ }^{7}$ The discrepancies between the awareness of the existence of wildlife conservations in the students' areas of residence and the level of knowledge on this subject are typical not only of the respondents - a similar situation has been observed in case of students of post-secondary schools in Katowice (Hibszer, Hibszer, 2012).
Students living in the countryside are more aware of the existence of wildlife conservation areas than their peers from the city $(73.2 \%$ students from the countryside, $70.8 \%$ - students from the city). This is most numerously represented by the students from high schools in Wieruszów (93.6\%), Pajęczno (91.7\%) and Tomaszów Mazowiecki (91.2\%). In the area of Wieruszów and the wieruszowski powiat, the Prosna valley is considered an area of protected landscape, the forested areas near the village of Ryś constitute the "Ryś" nature preserve, and the area of the natural occurrence of the royal fern species of fern - with a section of an over hundred years old moist forest in Węglowice - comprise a "Długosz Królewski" preserve (PRogram OCHRONY ŚRoDOWISKA..., 2008). Despite the quite small surface area of the wildlife conservations in the wieruszowski powiat, and their average rank compared to national parks or strict nature preserves, the awareness of the existence of interesting nature elements that are worthprotecting is the highest among the students of the high school in Wieruszów compared with the respondent students in the whole voivodeship.

The high awareness of the existence of wildlife preserves is influenced by the students' places of residence - more than $50 \%$ of students come from rural areas which contain at least one nature monument. Therefore, these students have higher chances of encountering the protected wildlife than their peers from the city. In case of Pajęczno and Tomaszów Mazowiecki, their location in the direct neighbourhood of landscape parks (Załęczański PK and Spalski PK), in which educational activities often take place, positively influences the ecological awareness of the youth (ADAMCZEWSKA, 2008). A similar situation has also been observed in other places located nearby landscape parks. $86.4 \%$ to $89.5 \%$ of the respondents from Przedbórz, Łódź and Wieluń indicated the existence of wildlife conservation areas in the neighbourhood of their homes. A high index has also been noted down in Skierniewice and Piotrków Trybunalski $(79.6 \%$ and $77.4 \%$ respectively). The lowest index (37.3\%) was determined in the respondents from Opoczno. Despite the opoczyński powiat comprising parts of both Sulejowski PK and Spalski PK landscape parks, 244 nature monuments and 5 nature preserves (RAPORT 0 STANIE ŚRODOWISKA..., 2013), the awareness of their existence among students was low ${ }^{8}$. 8 Opoczno is one of the main centres of the rawsko-opoczyński
etnographic region, which cultivates folk traditions (craft and
traditional attire, amongst others) and it is exactly the folk 
$40.5 \%$ of respondents from Bełchatów stated that there are areas or individual objects considered wildlife preservation sites in their neighbourhoods, in Pabianice this percentage amounts to 48.9. The respondent students are mostly residents of cities (Bełchatów $-83.5 \%$, Pabianice $-75 \%$ of the students), where only single trees are protected by law (nature monuments), and there are no nature preserves or landscape parks.

The students, while enumerating the examples of natural objects protected by law, listed mostly individual trees as animate nature monuments, nature preserves and landscape parks (sporadically, they enumerated Obszary Natura 2000 among the wildlife conservation areas). They gave proper names of landscape parks, yet the majority only listed the preserves as a form of wildlife conservation in their neighbourhoods, with few able to name the given preserve and point out the subject of protection therein (por. HiBSzER \& HIBSZER, 2012).

The existence of areas protected by law in the students' places of residence and their neighbourhoods positively influences the creation of ties that connect youth to their homes, and, therefore, shape their identity. A positive impact is also supplied by other, not necessarily protected areas, which, due to the picturesque landscape, fresh air, the possibility of providing quiet and peaceful leisure, are valuable by itself. The positive aspects of the natural environment are listed by the students as one of the major features of their areas of residence to take pride in (Fig. 4) 9

$67.8 \%$ of all the respondents is proud of their area of residence. The open nature of the survey question asking about the reasons for being proud of a person's home area resulted in diverse answers. In order to provide a further analysis, they were grouped according to theme, which enabled the distinction of 8 groups (Fig. 4). The positive aspects of nature, in the broad understanding (that is landscape parks, nature preserves, forests, places with picturesque landscapes, clean environment, quiet, peace, access to waters mainly rivers but also parks that were once parts of manor estates and city parks, green squares and other greenery areas in cities), have been put by the students in third place of all enumerated

culture, not the natural environment that predominates on the level of regional education.

${ }^{9}$ In the research conducted by K. Rembowska (2002) on the subject of the regional identity of the residents of the Łódź Voivodeship, the positive aspects of the natural environment („clean environment, a lot of greenery, no pollution”) were identified as the advantages of the inhabited regions and considered an asset of the Łódź area. reasons for being proud. Only historical events and historic objects as well as the attitude of local people were more often listed as pride-inducing. The advantages of clean, picturesque environment, free from the hubbub of the city, are most appreciated by the students from Tomaszów Mazowiecki10, Koluszki (more than $30 \%$ of indications), Brzeziny, Rawa Mazowiecka (circa $23-26 \%$ of indications). The students from Przedbórz, Poddębice, Łask and Opoczno are also proud of the natural environment (more than $16 \%$ of indications). The existence of large forest complexes ${ }^{11}$ or wildlife conservations nearby (even if the students are not fully aware of their existence as in, for example, Opoczno, they still see and appreciate the value of the natural environment they live in) and the location by the rivers are the reason for the youth's greater contact with nature. Both adults and students in rural areas and small towns are more likely to see the value of the natural environment than their peers in large cities and agglomerations (REMBOWSKA, 2002; SZKURŁAT, 2004). The results of the conducted research also confirm that the above-mentioned towns (Poddębice, Przedbórz, Opoczno, Łask) are considered either small or average, and around $46-51 \%$ of students that attend schools there come from rural areas. High schoolers from Wieruszów are the exception - despite their awareness of the existence of protected regions in their areas of residence being the highest, they do not perceive the natural environment as the reason to boast. In Wieruszów the things to feel proud of comprised elements associated with cultural and entertainment activities - the ice rink and the voluntary fire brigade with its brass band. It is mostly due to a number of the students being part of the band that plays by the fire brigade, while the ice rink is not only the place to spend free time, but also one of the structures that set Wieruszów apart from the neighbouring towns.

The lack of correlation between the high awareness of the existence of areas valuable in nature, protected by law, and perceiving them as worth being proud of, has also been observed in Skierniewice and Łowicz. These towns are considerably larger than Wieruszów both in terms of population ( 5 and 3 times the size), and area size, but, above all, are characterized by distinct predominant features - "showpieces". In case of

\footnotetext{
${ }^{10}$ Nature preserve „Niebieskie Źródła” was most frequently listed as the reason for being proud. The students emphasized the uniqueness of the preserve not only in Poland but also in the whole of Europe.

11 Poddębice are the exception.
} 
Skierniewice these comprise the fruit farming and railway (the Warsaw-Vienna train track) traditions, and in Łowicz - the folk culture; these determine

the recognizability of towns, which decreases the natural elements' pride-inducing prestige.

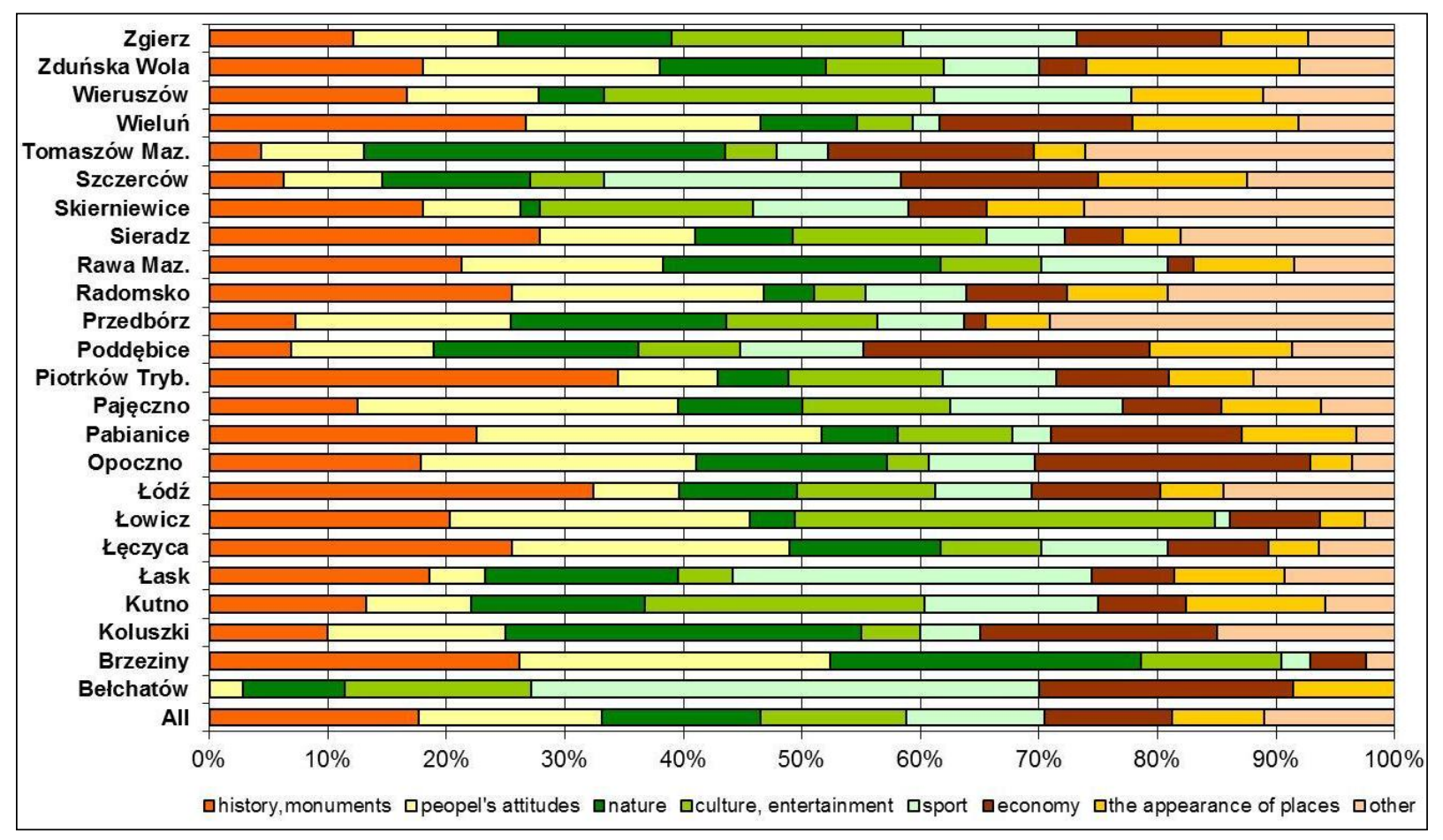

Fig. 4. Reasons to take pride in the place of residence (by the number of indications)

A crucial role in creating ties and shaping identities is played by important, unique places with a specific atmosphere and climate, in literature called "magical places" (JAŁOWIECKI \& SZCZEPAŃSKI, 2002). To determine what kinds of places are significant and exceptional to the students, they were asked to enumerate them and write a brief explanation. The open form of the question enabled the freedom of answer. The diversity in the students' responses was high - there were divided into 11 categories of places considered important by the respondents (Fig. 5). Areas interesting in terms of nature were most often listed as "magical places" among the respondent group. According to the interviewed, fascinating places in nature are not necessarily preserves or conservation areas (Fig. 5) ${ }^{12}$, but places with unique landscapes, picturesque, quiet areas, historic parks and tree avenues, but also greeneries in cities (city parks, green squares). Young people appreciate those places as spaces where they can relax, think

\footnotetext{
12 The positive assessment of green areas by high school students is characteristic of students not only from the Łódź Voivodeship. In the research conducted by Awramiuk (2009) among the students from Podlachia, the green areas were also perceived positively and considered likeable and important. Also, the majority of geography studens of the University of Łódź interviewed by Rembowska (the research conducted in 1994) considered nature a „special” area, a refuge offering peace, quiet, isolation and clean environment.
}

about important matters, give their minds some rest and, at the same time, they constitute areas where they can meet and take walks with friends or love interests. These places are also significant, as they enable the chance of spending their free time in an active way with friends (e.g. walks, swimming, cycling). The diversity of natural areas in the cities is considerably lower than in rural regions, the most common ones include city parks, green squares or nature preserves. City parks often house public, occasional events (sport or entertainment events, concerts, outdoor film shows) which additionally raise the rank of parks as meeting places or places of rest and recreation.

Attractive natural areas are of an important status for the young people from Koluszki, Przedbórz, Zgierz, Tomaszów Mazowiecki and Szczerców (30.8-42.9\% of indications). Students from Przedbórz and Tomaszów Mazowiecki consider areas within the landscape parks (Przedborski and Spalski landscape parks) in the direct neighbourhood of Pilica as most important places. Unique areas, for the youth from Koluszki, similarly to a part of the students from Szczerców, constitute those "far from the everyday hubbub" with their peaceful and quiet atmosphere. The remaining students focus mainly on recreational purposes and, consequently, the possibility of leisure and playing with their peers. 


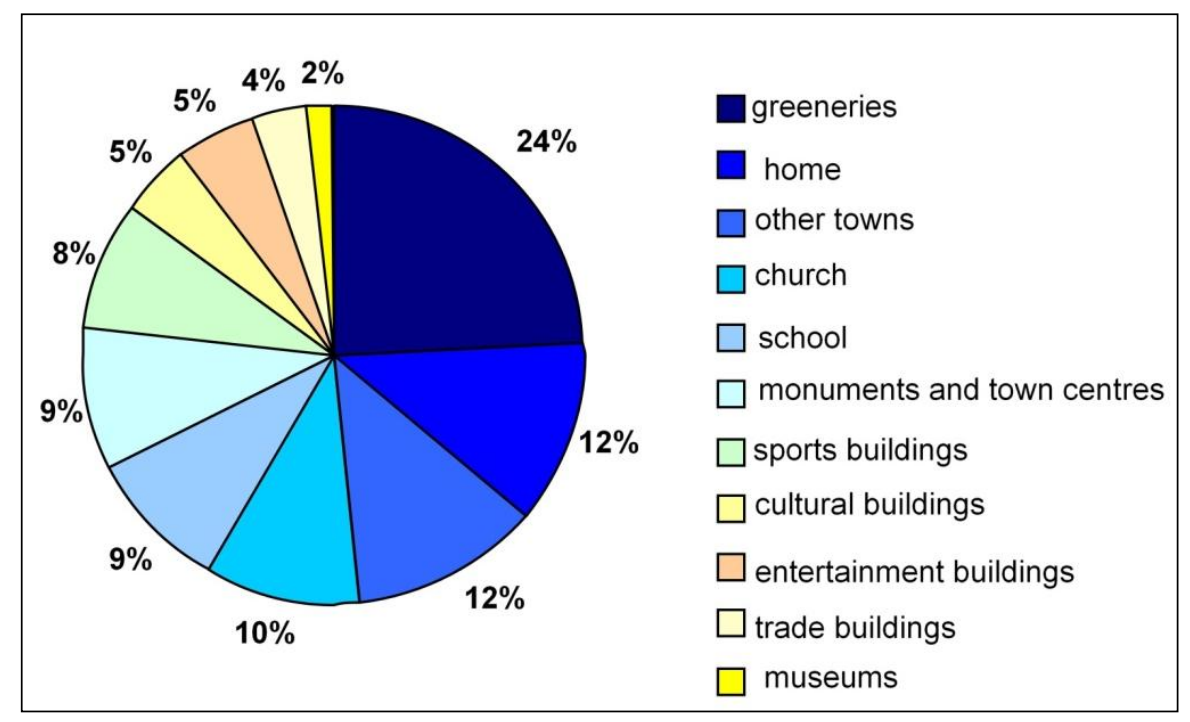

Fig. 5. Places important to the students (\% of indications)

\section{Conclusions}

The positive aspects of the natural environment sensu stricto, especially in areas with varied landforms, higher relative altitudes (southern and central part of the voivodeship, including: the Wieluńska Upland, Wzgórza Radomszczańskie, Pasmo Przedborskie, Wzniesienia Łódzkie) and regions within or in close neighbourhood of protected areas (the Wzniesień Łódzkich, Załęczański, Przedborski, Spalski landscape parks, the "Niebieskie Źródła" nature preserve, the nature preserve of the Rawka river), play a major role in the lives of young people. The importance of these areas is, above all, the result of them being positively perceived by the youth (as quiet, peaceful, calm, picteresque, cheerful places). A location becomes unique when a student associates it with positive aspects (a place known from childhood, associated with numerous playtimes; a place to spend time in a nice atmosphere with friends and family; a place in which to think about significant matters, meditate, etc.). Thanks to the relations based on positive emotions, these places become important to the students (TUAN, 1974) and constitute a crucial factor influencing the strengthening of ties with the place of residence and, therefore, shaping the regional identity of the youth.

In case of the high schoolers from the Łódź voivodeship, the role of the positive aspects of the natural environment in shaping the sense of regional identity is largely determined by the young people's places of residence (city - countryside). Nature areas are to be proud of and are considered important places to spend a large amount of free time with friends by students living in rural areas and small towns (Koluszki, Przedbórz, Szczerców, Łask, Brzeziny, Pajęczno, Wieluń13). Students living in bigger towns also appreciate greenery (Zgierz, Pabianice, Tomaszów Mazowiecki, Rawa Mazowiecka, Łódź). City parks, forests (e.g. Łagiewniki in Łódź), nature preserves for them constitute a place to rest from noise and the city hubbub, and simultaneously are favourite places to meet friends. Moreover, occasional events and fairs organized in parks by the local authorities or social institutions make the locations more attractive in the eyes of young people. Furthermore, students have a sentimental attachment to parks in which they spent time as kids with their parents and grandparents.

Places where nature enchants with its beauty remain in human memory for long years; the indelible impressions prompt a en eager return thereto. Areas associated with childhood are especially valued, since at that age discovering the world, aside from the educational values, carries with it a huge emotional charge (RoDzoś, 2006). The results of the conducted research confirm the thesis of the importance of the natural environment's role in the shaping of the regional identity of young people.

\section{References}

Adamczewska M. 2008. Rola obszarów przyrodniczo cennych w edukacji geograficznej na przykładzie województwa łódzkiego. [in:] Gierańczyk W., Wiśniewski R. (eds.) Geografia we współczesnym systemie kształcenia. Dokum. Geogr., 38, PAN IGiPZ im. S. Leszczyńkiego, PTG, Warszawa: 18-23.

$1363 \%$ of high schoolers from Wieluń were students commuting from rural areas, considering nature as important, therefore Wielun, in spite of being a large town, was included in the described group. 
Adamczewska M., Szkurłat E. 2008. Związki pomiędzy wiedzą o Polsce i regionie a postawą młodzieży, [in:] Plit F. (ed.) Dylematy nauczania geografii Polski. Prace i Studia Geogr., 39, Wydz. Geogr. i Studiów Regionalnych UW, Warszawa: 11-22.

Angiel J., Angiel M. 2001. Dydaktyczna ścieżka przyrodniczogeograficzna "Pogórze Karpackie" Pogórze Wiśnickie, okolice Bochni. IGiGP UJ, Kraków.

Awramiuk A. 2009. Pogranicze kultur. Percepcja „własnego regionu" przez uczniów a edukacja regionalna. Wyd. UW, Warszawa.

Burchard J., Nalewajko J. 2000. Indywidualność środowiska przyrodniczego województwa łódzkiego i jego antropogeniczne przeobrażenia. [in:] Sobczyński M. Michalski W. (eds.). Województwo łódzkie na tle przemian administracyjnych Polski. $W$ osiemdziesiąta rocznice utworzenia województw. PTG Oddz. w Łodzi, Rządowe Centrum Studiów Strategicznych (RCSS), Biuro Rozwoju Regionalnego w Łodzi, Łódź: 23-54.

Dobosik B., Hibszer A., Partyka J. (ed.) 2004. W krainie białych skał. Zadania dydaktyczne i scenariusze zajęc terenowych dla nauczycieli prowadzacych edukację przyrodnicza $w$ Złotym Potoku i Ojcowie. Komisja Edukacji Geogr. PTG, Ojcowski Park Narodowy, Ojców.

Dylik J. 1971. Województwo ze stolicq bez antenatów. Łódzkie Tow. Nauk., Łódź.

Dylikowa A. 1973. Geografia Polski. Krainy geograficzne. PZWS, Warszawa.

Górecki W. 2001. Energia geotermalna w Polsce. Ministerstwo Środowiska, Warszawa.

Hibszer A. 2004. Empiryczny wymiar edukacji przyrodniczej na przykładzie Wyżyny Krakowsko-Częstochowskiej. [in:] Partyka J. (ed.) Zróżnicowanie i przemiany środowiska przyrodniczo - kulturowego Wyżyny KrakowskoCzęstochowskiej, 2 - Kultura. Wyd. Ojcowski Park Narodowy, Ojców: 351-356.

Hibszer A., Hibszer B. 2012. Formy ochrony przyrody na obszarze Katowic w świadomości uczniów szkół ponadgimnazjalnych. Kształt. środ. geogr. i ochr. przyr. na obsz. uprzem. i zurban., 44: 41-49.

Jałowiecki B., Szczepański M. 2002. Miasto i przestrzeń w perspektywie socjologicznej. Wyd. Nauk. Scholar, Warszawa.

Janowski I. 2003. Rezerwaty przyrody i ich wykorzystanie edukacji regionalnej. [in:] Śmigielska M., Słodczyk J. (ed.) Edukacja geograficzno-przyrodnicza $w$ dobie globalizacji $i$ integracji europejskiej, Pol. Tow. Geogr., Uniw. Opolski, Opole: 79-84.

Jaworska R. 2009. Wykorzystanie wód geotermalnych w województwie łódzkim na przykładzie Geotermii Uniejów sp. z o.o. [in:] Sokołowicz M.E. (ed.) Miasta i regiony wobec współczesnych wyzwań. Wyd. Uniw. Łódzkiego, Łódź: 117-128.

Jokiel P. 2004. Zasoby wodne Środkowej Polski na progu XXI w. Wyd. Uniw. Łódzkiego, Łódź.

Kondracki J. 1965. Geografia fizyczna Polski. PWN, Warszawa.

Kondracki J. 1998. Geografia regionalna Polski. Wyd. Nauk. PWN, Łódź.

Leśnictwo 2014. GUS, Warszawa.

Lisowski A. 2003. Koncepcje przestrzeni w geografii człowieka. Wydz. Geogr. i Studiów Region. Uniw. Warszawski, Warszawa.

Majchrowska A. 2008. Systematyzacja krajobrazów w wybranych krajach europejskich. [in:] Lechnio J., Kulczyk S., Malinowska E., Szumacher I. (eds.) Klasyfikacja krajobrazu. Teoria i praktyka. Problemy Ekologii Krajobrazu, t. XX, Wydz. Geogr. i Studiów Regionalnych Uniw. Warszawski, Polska Asocjacja Ekologii Krajobrazu, Warszawa: 127-134.
Maksymiuk Z. 1993. Wody powierzchniowe i podziemne. [in:] Pączka S. (ed.) Środowisko geograficzne Polski Środkowej. Wyd. Uniw. Łódzkiego, Łódź: 94-108.

Maksymiuk Z. 2001. Wody. [in:] Liszewski S. (ed.) Zarys monografii województwa łódzkiego. Funkcja regionalna Łodzi i jej rola $w$ kształtowaniu województwa. Łódzkie Tow. Nauk., Łódź: 60-68.

Maksymiuk Z., Olaczek R. 2001. Indywidualność przyrodnicza regionu łódzkiego. [in:] Liszewski S. (ed.) Zarys monografii województwa łódzkiego. Funkcja regionalna Łodzi i jej rola $w$ kształtowaniu województwa. Łódzkie Tow. Nauk., Łódź: 49-51.

Myga-Piątek U. 2001. Spór o pojęcie krajobrazu w geografii i dziedzinach pokrewnych. Przegl. Geogr., 73, 1-2: 163-176.

Kurowski J.K. (ed.) 2013. Obszary NATURA 2000 w województwie łódzkim. Region. Dyr. Ochr. Środ. w Łodzi, Łódź.

Ochrona środowiska i leśnictwo $w$ województwie łódzkim $w$ latach 2011-2013, 2014. Urząd Statystyczny w Łodzi, Łódź.

Ostaszewska K. 2005. Krajobraz - środowisko geograficzne środowisko przyrodnicze. [in:] Maik W., Rembowska K., Suliborski A. (eds.) Geografia jako nauka o przestrzeni, środowisku i krajobrazie. Podstawowe idee i koncepcje $w$ geografii, 1. Zakł. Geogr. Społecznej i Turystyki UML, Zakł. Badań Społecznych i Regionalnych, Uniw. Łódzki, Łódz. Tow. Nauk., Łódź: 162-172.

Papińska E. 1993. Podział regionalny i nazewnictwo geograficzne obszaru Środkowej Polski.[in:] Pączka S. (ed.) Środowisko geograficzne Polski Środkowej. Wyd. Uniw. Łódzkiego, Łódź: 11-19.

Pietrzak M. 2005. Ewolucja poglądów geograficznych na krajobraz.[in:] Maik W., Rembowska K., Suliborski A. (eds.) Geografia jako nauka o przestrzeni, środowisku $i$ krajobrazie. Podstawowe idee i koncepcje w geografii, 1. Zakł. Geogr. Społecznej i Turystyki UML, Zakł. Badań Społecznych i Region., Uniw. Łódzki, Łódz. Tow. Nauk., Łódź: 151-161.

Program ochrony środowiska województwa łódzkiego 2012. Zarząd Woj. Łódzkiego, Woj. Funduszu Ochr. Środ. i Gosp. Wod. w Łodzi.

Program Ochrony Środowiska Powiatu Wieruszowskiego 2011 z perspektywą na lata 2012-2015 (projekt). Zarząd Powiatu Wieruszowskiego, Wieruszów, 2008.

Pulinowa M.Z. (ed.) 1996. Człowiek bliżej Ziemi. O teoretycznych podstawach nauczania geografii $i$ ich praktycznym zastosowaniu. WSiP, Warszawa.

Pulinowa M.Z. 2001. O idei krajobrazu. Gazeta Uniwersytecka, 5, Katowice: http://gazeta.us.edu.pl/node/207791.

Rocznik statystyczny województwa łódzkiego, 2014. Urząd Statystyczny w Łodzi, Łódź.

Raport o stanie środowiska $w$ województwie łódzkim $w 2012$ roku. Woj. Inspektorat Ochr. Środ. w Łodzi, Biblioteka Monitoringu Środowiska, Łódź.

Rembowska K. 2002. Tożsamość regionalna mieszkańców województwa łódzkiego.[in:] Jewtuchowicz A. Suliborski A. (eds.) Struktury i procesy kształtujące łódzki region społeczno-gospodarczy. Uniw. Łódzki, Zakł. Ekonomiki Region. i Ochr. Środ., Łódź: 61-77.

Richling A., Solon J. 1996. Ekologia krajobrazu. PWN, Warszawa.

Rodzoś J. 2006. Tożsamość terytorialna jako wyraz więzi człowieka ze środowiskiem. [in:] Michalczyk J. (ed.) Człowiek a środowisko. Katol. Uniw. Lubel. Jana Pawła II, Kuratorium Oświaty w Lublinie, Lublin: 45-50.

Smętkiewicz K. 2014. Świadomość społeczna wykorzystania wód geotermalnych $w$ województwie łódzkim i landzie Styria w kontekście zrównoważonego rozwoju regionów. Wyd. Ibidem, Łódź. 
Szczepański M.S. 1999. Tożsamość regionalna - w kręgu pojęć podstawowych i metodologicznych. [in:] Matczak A. (ed.) Badania nad tożsamością regionalną: stan i potrzeby. Mat. konf. nauk., Krajowy Ośr. Dokum. Region. Tow. Kultury w Ciechanowie, Łódź: 7-17.

Szkurłat E. 2004. Więzi terytorialne młodzieży z miastem. Wyd. Uniw. Łódzkiego, Łódź.
Szul R. 1991. Przestrzeń - gospodarka - państwo. Rozwój regionalny, rozwój lokalny, samorząd terytorialny, 26, Inst. Gosp. Przestrz. Uniw. Warszawski, Warszawa.

Szymańska D. 1999. Kilka uwag na temat tożsamości regionalnej. [in:] Matczak A. (ed.) Badania nad tożsamościq regionalną: stan i potrzeby. Mat. konf. nauk., Krajowy Ośr. Dokum. Region. Tow. Kultury w Ciechanowie, Łódź: 70-73.

Tuan Y.-F. 1987. Przestrzeń i miejsce. PIW, Warszawa. 